\title{
Using English Instructional Module by B-SLIM Model to Promote English Reading Comprehension of High School Students
}

\author{
Sombat Ramat, Nattapakal Kittisunthonphisarn, and Kanokkarn Kittichartchaowalit
}

\begin{abstract}
This research objectives were to develop the English Instructional Module by B-SLIM Model, to compare the learning achievement between pretest and posttest of using English Instructional Module by B-SLIM Model and to study their satisfaction of English Instructional Module by B-SLIM Model. The participants were high school students in the first semester, academic year 2014 at Suratpittaya School, Suratthani. The instruments used in the study were 1) English Instructional Module by B-SLIM Model 2) 30 items of achievement test and 3) students' satisfaction. The data were statistically analyzed by percentage, mean, standard deviation and t-test for dependent.

The research findings indicated that the English Instructional Module by B-SLIM Model for high school students have the efficient at 84.82/80.98 and the learning achievement after applying the English Instructional Module by B-SLIM Model was increased significantly at .05 level. The level of students' satisfaction of high school students was at a very high.
\end{abstract}

Index Terms-B-SLIM model, comprehension, English instructional module, reading.

\section{INTRODUCTION}

English is communicated all over the world. We use English to exchange information, knowledge, culture, custom and tradition. Therefore, English is the most important for Thais' daily lives. They use English through media e.g. newspapers, magazines, ads signs and internet which relate to teaching English procedure, especially reading skill. It is the most effective and necessary skill for learners to transfer their idea to further education and career.

Thai government emphasizes on preparing readiness of Thailand for driving development of ASEAN Community within 2015 by focusing more on practices and connection for benefits of regional people as shown in Declaration of Cha Am - Hua Hin regarding Action Plan for ASEAN Community during 2009-2015. As a result, English is the most important language to communicate in ASEAN. As it is shown in ASEAN Rule No.34 "The working language shall be English According to [1] said that English is taught from primary school to lifelong learning.

Manuscript received October 15, 2014; revised December 22, 2014. Sombat Ramat is with Foreign Language Department, Surattpittaya School, Suratthani, Thailand (e-mail: keawglass@hotmail.com).

Nattapakal Kittisunthonphisarn is with Faculty of Architecture and Design, Rajamangala University of Technology Rattanakosin, Nakhonpathom, Thailand, 73170.

Kanokkarn Kittichartchaowalit is with Graduate School, Suratthani Rajabhat University, Suratthani, Thailand.
According to the purpose of [2], teaching procedure is very important. The students in primary must study English until they graduate from the university, but the weak point of reading skill is not improved. It is related to [3] which said that Thais learners showed the weakness of reading competence.

The most popular teaching aids are 1) Instructional Package 2) Teacher-Made kits 3) Programmed Instruction 4) Instructional Module. This Instructional Module is one of the teaching aids which we used to improve preparation teaching English, related to [4], she said that the ability after using module in reading skill was higher than before and learners' satisfaction was high.

There are many kinds of English teaching styles e.g. Project Method, Community Language Learning and Communicative Approach. They are communicative approach that focus on not only grammar but also on communication. The teachers have to encourage students to use language to communicate. B-SLIM Model (Bilash's Second Language Instruction Model) by [5] is a kind of teaching styles that include 5 teaching steps 1) Planning and Preparation 2) Comprehensible Input 3) Intake Activity 4) Output and 5) Evaluation.

The activities are classified from easy to difficult ones, so the students are happy to learn and positive attitude towards English. Wichai Srimahan found that teaching by B-SLIM Model can improve the students' ability.

\section{PURPOSE}

1) To develop the English Instructional Module by B-SLIM Model.

2) To compare the learning achievement between pretest and posttest of using English Instructional Module by B-SLIM Model.

3) To study the satisfaction of using English Instructional Module by B-SLIM Model.

\section{RESEARCH DESIGN}

The data was gathered and analyzed as follow:

\section{A. Population and Sampling}

1) The population is the first semester high school students at Suratpittaya school, Suratthani, Thailand of academic 2014. There were 550 students from 13 classes.

2) The sample of 44 students and was derived from a simple random sampling technique as a class unit. 


\section{B. Duration in Experiment}

The experiment ran for 10 weeks ( 2 hours a week)

\section{Variables}

Variables in this study were as follows:

1) The efficiency of satisfaction of using English Instructional Module by B-SLIM Model was the specific standard criteria of $80 / 80$

2) The learning achievement between pretest and posttest of using English Instructional Module by B-SLIM Model.

3) The satisfaction of using English Instructional Module by B-SLIM Model

\section{Research Instruments}

1) English Instructional Module by B-SLIM Model 4 units

2) A 1-hour English reading proficiency test (30 items : 30 scores)

3) A questionnaire constructed by the researcher assessing satisfaction with using English Instructional Module by B-SLIM Model.

\section{E. Construction and Development of Research Instruments}

The researcher constructed English Instructional Module by B-SLIM Model and proficiency test in the following way:

First, the researcher studied the format of module lesson Srinakkharinwirot University's and [6]. The contents based on The Basic Education Core Curriculum and focus on English reading skill and strategies. Emphasis was placed on reading topic for skimming, scanning, finding topic and main idea, finding details, guessing meaning, pronoun reference and making inference.

Second, the researcher derived 4 units from content based on high school. They are 1) Technology, 2) Work and Travel, 3) Television, 4) Environment, then the unit of contents specification was designed by determining the objective, content, topic, reading activities and evaluation.

Finally, the constructed units were examined for IOC by experts and lesson plans were written for all 4 units. Each lesson plan was composed of B-SLIM Model. The unit tests consisted of a multiple choice test, sequencing events, information gap, and question answering.

\section{F. Proficiency Test}

Students were given pre and post class proficiency test. The test had the same format and consisted of 30 items (30 scores). The duration of each test was 60 minutes. The researcher used the text book, newspaper, journal articles and websites. The researcher also, created a table of specifications including reading skill and goal for each unit, and then created one set of proficiency tests.

The researcher derived the difficulty and discrimination of the tests (P-R value) from standard criteria consisting of 30 items. Three experts examined, corrected and improved the accuracy, validity and reliability of language and contents of the test. The tests had a difficulty level between 0.27-.0.79, a rank of discrimination between $0.21-0.52$ and reliability at 0.81 . The calculation of the test reliability was use K-R 20 by Kuder-Richardson [7]. Then, the proficiency test was used to sampling of the research.

\section{G. The Satisfaction Questionnaire}

The researcher created a questionnaire to investigate students satisfaction with English Instructional Module by B-SLIM Model. The questionnaire was constructed using both closed-end and opened-end questions. The answer to each question was separated by Likert.

Question rated less than 0.5 by the experts were considered and improved. The data obtained from a small group experiment was analyzed to find reliability by using the $\alpha$ -Coefficient formula stated by [8] Cronbach coefficient of reliability was 0.90

\section{H. Data Collection}

The class was first test on a single student, and then on a small group students before being used on an acrual class. Therefore, there were three phases of data collection:

One high school student who was not included in the test group went through English Instructional Module by B-SLIM Model and took the 30-question pre- and post- test. This enanble the researcher to investigate behavior, listen to the student's ponit of view, answer questions, trobleshoot problems with the 4 units and the proficiency test $80.11 / 80.42$

A small group of 6 students then took English Instructional Module by B-SLIM Model with test offer each units and took the post-test. In this phase, the researcher recorded the problems and suggestions in order to improved the effectiveness of the unit. The scores ferived from each unit and scores from ability post-test were calculated as $80.60 / 81.02$

Next, 44 students took the reading course and the post-test. The scores derived from each unit and scores from post-test were claculated at 84.82/80.98

Students scored 1,493 out of $1,760(84.82 \%)$ on the unit tests. On the post-test, students scored 1,069 out of 1,320 $(80.98 \%)$

\section{Statictic Used in Data Analysis}

1) The Unit effectiveness was determined by using $E_{1} / E_{2}$ formula follow 80/80 criteria.

2) The comparison between the pretest and posttest was done using t-test, which was calculated by SPSS/PC

3) The data from the questionnnaire were rated to find the mean and standard deviation

\section{J. Result of Data Analysis}

TABLE I: THE RESULT OF THE EFFICIENCY OF ENGLISH INSTRUCTIONAL MODULE BY B-SLI M MODEL

\begin{tabular}{l|c|c|c|c}
\hline \multirow{2}{*}{ Items } & Students & $\begin{array}{c}\text { Full } \\
\text { score }\end{array}$ & $\begin{array}{c}\text { Total } \\
\text { score }\end{array}$ & $\begin{array}{c}\text { Efficiency } \\
\text { Value }\end{array}$ \\
\cline { 2 - 4 } & $N$ & Total & $\sum \mathrm{x}$ & \\
\hline Score while studying $\left(\mathrm{E}_{1}\right)$ & 44 & 40 & 1,493 & 84.82 \\
\hline Score after studying $\left(\mathrm{E}_{2}\right)$ & 44 & 30 & 1,069 & 80.98 \\
\hline \hline
\end{tabular}

Tests were given to all 44 students after each of the units. The results indicated that the efficiency value of English Instructional Module by B-SLIM Model was 84.82 and 80.98 , which was higher than the standardized criteria (see Table I, Table II, and Table III).

The post-test scores were higher than the pre-test scores by 0.05 ( $\operatorname{sig}=0.00<0.05)$. The mean score of the post-test was 25.00 higher than the pre-test (19.95 out of 30) The different 
between pre-test and post-test was 5.05 and for the t-test it was 7.76.

Result indicated students reading ability was improved by affirming hypothesis 2

TABLE II: THE RESUlT OF THE STUDY ACHIEVEMENT

\begin{tabular}{c|c|c|c|c|c|c}
\hline \hline & $\mathbf{N}$ & $\bar{X}$ & S.D. & \multirow{D}{*}{} & $\mathbf{t}$ & Sig. \\
\hline Pre-test & 44 & 19.95 & 4.63 & & & \\
\hline Post-test & 44 & 25.00 & 2.33 & 5.05 & 7.76 & 000. \\
\hline \hline
\end{tabular}

TABLE III: THE RESULT OF THE LEVEL OF STUDENTS’ SATISFACTION

\begin{tabular}{l|c|c|c}
\hline \multicolumn{1}{c|}{ Items } & $\bar{X}$ & S.D. & Result \\
\hline Contents & 4.64 & 0.49 & highest \\
\hline 1. Contents are suitable with the objective & 4.45 & 0.59 & highest \\
\hline 2. Steps of the contents & 4.32 & 0.64 & highest \\
\hline 3. Each contents are appropriate & 4.50 & 0.63 & highest \\
\hline 4. Contents are suitable with students & 4.39 & 0.62 & highest \\
\hline 5. Contents are modern & $\mathbf{4 . 4 6}$ & $\mathbf{0 . 5 9}$ & highest \\
\hline \multicolumn{4}{c}{ Average of contents }
\end{tabular}

\begin{tabular}{|c|c|c|c|}
\hline \multicolumn{4}{|l|}{ Pictures and language } \\
\hline $\begin{array}{l}\text { 6. Pictures and language conform with } \\
\text { content }\end{array}$ & 4.02 & 0.70 & high \\
\hline Average of pictures and language & 4.02 & 0.70 & high \\
\hline \multicolumn{4}{|l|}{ Letters and color } \\
\hline 7. Type of letters are appropriate & 4.50 & 0.55 & highest \\
\hline 8. Size of letters are appropriate & 4.50 & 0.55 & highest \\
\hline 9. Color of letters are appropriate & 4.34 & 0.65 & highest \\
\hline 10. Backgrounds are appropriate & 4.23 & 0.74 & highest \\
\hline 11. Graphics are appropriate & 4.07 & 0.70 & high \\
\hline Average of letters and color & 4.33 & 0.64 & highest \\
\hline \multicolumn{4}{|l|}{ Test } \\
\hline 12. Test directions are clear & 4.61 & 0.58 & highest \\
\hline 13. Tests are appropriate with level & 4.43 & 0.66 & highest \\
\hline 14. Marks report are appropriate & 4.41 & 0.66 & highest \\
\hline 15. Difficulty of the tests & 4.11 & 0.65 & high \\
\hline 16. Numbers of the tests & 4.05 & 0.61 & high \\
\hline 17. Tests are suitable with objective & 4.88 & 0.59 & highest \\
\hline 18. Knowledge from modules & 4.52 & 0.50 & highest \\
\hline Average of test & 4.35 & 0.63 & highest \\
\hline \multicolumn{4}{|l|}{ How to manage modules } \\
\hline 19. Modules are easy to use & 4.30 & 0.63 & highest \\
\hline 20. Interesting design & 4.07 & 0.66 & high \\
\hline 21. Materials are appropriate for modules & 4.25 & 0.69 & highest \\
\hline 22. Modules are appropriate & 4.23 & 0.61 & highest \\
\hline Average of contents & 4.27 & 0.62 & highest \\
\hline Over all & 4.29 & 0.64 & highest \\
\hline
\end{tabular}

The results of the student satisfaction questionnaire were as follows:

The mean score of all items was $(\bar{x}=4.29)$, and S.D. $=0.64$. The highest mean score was contents $(\bar{x}=4.46)$, the second highest mean score was test $(\bar{x}=4.35)$ and the lowest mean score was picture and language $(\bar{x}=4.02)$. The result indicated high satisfaction, affirming hypothesis 3 .

\section{CONCLUSION}

According to the study and data analysis, the results of this study were as follows:

1) The efficiency of English Instructional Module by B-SLIM Model in this experiment was $84.82 / 80.98$ which was higher than determined criteria (80/80). It was demonstrated English Instructional Module by B-SLIM Model was very effective, confirming hypothesis 1 .

2) Ability in English reading comprehension after using English Instructional Module by B-SLIM Model was improved at statistical significant at 0.05 level, confirming hypothesis 2 .

3) Students satisfaction with English Instructional Module by B-SLIM Model was at the highest level, confirming hypothesis 3 .

\section{DISCUSSION}

The results of the study indicated:

1) The efficiency of English Instructional Module by B-SLIM Model.

There are 4 units which built a sequence of steps, including topic, ideas, objective, pre-assessment, activities and post-assessment [9].

The teaching learning activity in each unit was constructed according to an English reading theory develop by [10], [11]. They started learners with easy activities, progressing to more difficult activities for using English Instructional Module by B-SLIM Model. Furthermore, the learners used reading strategies to assist in reading comprehension [12]-[14].

2) The students' reading ability improved at the 0.05 level. This may be accounted for by the learner's satisfaction with interest in the requires contents. The lesson integrated teaching English reading with strategies which were familiar to high school students [15], [16].

3) Survey results indicated students were highly satisfied with using English Instructional Module by B-SLIM Model. They interested in content and the students use in everyday life. The content is consistent with the objective of the research. Consistent with the findings of [17] showed that this lesson module built successfully. It was received by the intended target.

\section{RECOMMENDATION}

1) Pictures and descriptions in module should be related to contents.

2) Teacher may use pictures, videos, animations from website or YouTube to encourage the students' interests.

3) Teacher should adapt various activities and the test shouldn't be too difficult.

Note:

4) Teachers should use B-SLIM Model to improve others teaching skill and adapt the content to suit the students level.

5) Teacher should develop both reading and writing skills 
together.

\section{ACKNOWLEDGMENT}

The authors would like to acknowledge Granduate School, Suratthani Rajabhat University, Thailand which gave the scholarship for my research. Experts as following 1) Mrs.Jiyani Promjeam 2) Mrs. Anna Theplearn and 3) Miss. Theeranart Theepapan, and high school students in the first semester, academic year 2014, Suratpittaya school, Thailand. They support this research.

\section{REFERENCES}

[1] S. Omwimon, "Home recording ASEAN," Koosangkoosom, vol. 33, pp. 16-17, June 2008.

[2] Ministry of Education, The Basic Education Core Curriculum Bangkok, 2000.

[3] N. Wamta, "Use of collaborative strategic reading and authentic materials to promote English reading comprehension and motivation among higher vocational certificated students," Chiang Mai, 2011,pp. 58-59.

[4] A. Kosasang, "The effectiveness of instructional module for teaching culture related in holiday of speakers of English for Mattayom three students," Choochon Tessaban 3 (Pinitpittayanusorn), Nakhon Phathom Province, Nakhon Phathom, 2003, pp. 143-145.

[5] O. Bilash, "Planning for writing instruction in a middle years immersion/partial immersion setting," Foreign Language Annals, vol. 31, no. 2, pp. 159-169, 1998.

[6] A. R. Arends, A. J. Masla, and A. W. Weber, "Handbook for the development of instructional modules in competency-based teacher education programs," Buffalo: State University College at Buffalo, 1972.

[7] B. Khajonsil, Education Research Methodology, Fifth Edition., Bangkok: P.N. Publishing, 2000.

[8] L. J. Cronbach, The Dependability of Behavior Measurement Theory of Generalizability for Scores and Profile, New York: Wiley Press, 1974.
[9] B. Kounhawech. (May 2014). Instructional Module. [Online] Available: http://senarak.tripod.com/odule2.htm.

[10] E. Williams, Reading in the Language Classroom, 8th ed., London: Macmillan Publisher Ltd., 1994.

[11] A. Luke and P. Freebody. (August 1999). Further notes on the four resources model. Reading. [Online]. Available: http://www.readingonline.org/research/lukefreebody.html

[12] D. Young and R. Oxford, "A gender-related analysis of strategies used to process input in the native language and foreign language," Applied Language Learning, vol. 8, pp. 43-73, 1997.

[13] P. Carrell, "Metacognitive awareness and second language reading," Modern Language Journal, vol. 73, pp. 121-13, 1989.

[14] A. J. Harris and R. S. Edward, How to Teach Reading, New York: Longman Inc., 1979.

[15] M. Barnett, "More than meets the eye: Foreign language reading: Theory and practice," Tappan, NJ: Language in Education. (ERIC Document Reproduction Service No. ED305829, 1988.

[16] W. Grabe, "Research on teaching reading," Annual Review of Applied Linguistics, vol. 24, pp. 44-69, 2004.

[17] J. A. Bennett, "Development and field testing reading instruction proficiency modules for in service teacher of secondary basic English reading class," Dissertation Abstract International, vol. 37, no. 12 , 1977

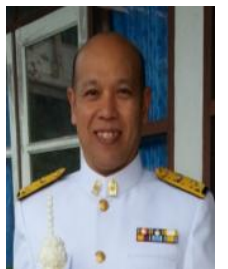

Sombat Ramat was born in Suratthani, Thailand in 1965. He studied English major and received his B.E. degree from Suratthani Teacher College, Suratthani, Thailand, in 1988 and the graduate diploma in English teaching program from Suratthani Rajabhat University Suratthani, Thailand, in 2007

In 1994, he joined Kuansubanwittya School, as a teacher, and in 1996. He is currently working as an English teacher in Suratpittya School, Suratthani, Thailand.

During his 20 years of experience he occupied different positions in academic and administration. His research interest is teaching English as foreign language. $\mathrm{He}$ is also interested in developing new teaching methodologies in the class room. He would like to develop instructional module of online lessons of Suratthani local wisdom. 